\title{
Drip Irrigation Detection for Power Outage-Prone Areas with Internet-of-Things Smart Fertigation Managemant System
}

\author{
Dahlila Putri Dahnil ${ }^{1}$, Zaihosnita Hood ${ }^{2}$, Afzan Adam ${ }^{3}$ \\ Center for Software Technology and Management ${ }^{1,2}$ \\ Center for Artificial Intelligence and Technology ${ }^{3}$ \\ Faculty of Information Sciences and Technology \\ Universiti Kebangsaan Malaysia, Bangi, Selangor, Malaysia
}

\author{
Mohd Zulhakimi Ab Razak ${ }^{4} *$, Ahmad Ghadafi Ismail ${ }^{5}$ \\ Institute of Microenginnering and Nanoelectronics \\ Universiti Kebangsaan Malaysia \\ Bangi, Selangor, Malaysia
}

\begin{abstract}
In drip irrigation agriculture or fertigation technique, sufficient amount of water and nutrients are crucial for a plant's growth and development. An electronic timer is usually used to control the plant watering automatically and the scheduling is set according to different levels of plant growth. The timer has to be adjusted frequently since the required amount of water is different according to the growth stages. In power outage-prone regions, the problem with scheduled irrigation using timer becomes worsen since the watering schedule is disrupted by occasional black-outs, leading to an insufficient supply of water and nutrients, which leads to poor crop yields. Typical solution for such problems is by hiring field works to monitor the functionality of the automated system, plant health, and to re-adjust the timer once a power outage occurs. However, this solution is ineffective, time-consuming, and acquires high overhead costs. This paper proposes a systematic irrigation method using the internet-of-things (IoT) framework in order to improve the monitoring of plant growth and consequently improves the efficiency of the workflow. This systematic fertigation monitoring system consists of power outage alerts, and on-line notifications of plant irrigation, pesticide delivery, and polybag cleaning schedule. As a result, by using the proposed system, higher efficiency in farming management is achieved, with a $40 \%$ reduction in manpower, as compared to a typical fertigation-based farming system. This system demonstrates greater control over irrigation scheduling, plant growth, recording of pesticide scheduling automatically, and polybag cleaning, all of which will improve crop yields significantly.
\end{abstract}

Keywords-Irrigation technique; water and nutrient; automatic drip irrigation; crop; power-outage

\section{INTRODUCTION}

The advancement in technology has influenced modern farming methods significantly and agricultural environment particularly. The agricultural landscape has shifted from conventional farming to digitized farming with the merging of interrelated computing devices, sensors, and cloud edge [1-5]. In addition, the combination of engineering and computing technology, equipped with sensors for agricultural activities, has enabled smart farming [6]. As the demand for food sources increases around the world, irrigation has grown even more necessary to prevent famine and nutritional deaths [7].
Advanced irrigation techniques are essential in order to achieve efficient irrigation management, and an optimal agriculture management system will ensure productivity, and environmental and economic viability [7-10]. Most techniques, such as regulated deficit irrigation [11], automated drip fertigation [10,12-13] and precision irrigation systems offer the opportunity to conserve irrigation water, improve fruit quality, increasing crop yield and decreasing costs while contributing to environmental sustainability [14-15].

The motivation of this study is to improve the management system of the irrigation scheduling by providing farmers with real-time feedback during irrigation so that they are notified of any abrupt loss of electricity, and can act based on the information provided by the system. This enables farmers to decide which nutrients should be received by the plant by controlling the timing of the irrigation. The system is easy to deploy in existing drip fertigation systems, with a plug-andplay module insertion. The application also aims to provide farmers and farm workers with a user-friendly tool that facilitates the management of pesticides and drip maintenance. Instead of manually entering records, farmers can track pesticide schedules through the system, which makes the process more manageable. It is expected that the proposed system could improve the crops yield as well as equipped the farmers with an improved and smart farming management system. The results demonstrated that the developed system could effectively facilitate fertigation management for outageprone areas and substantially decrease the need for on-site monitoring.

The rest of the manuscript is organized as follows. Section 2 describes related work in the area of advanced irrigation. Section 3 describes the user-friendly platform of the proposed system. This section also describes the real-time irrigation feedback, which records current and past irrigation durations, as well as the alert system, which notifies farmers of any absence of electricity. Section 4 describes the implementation of the system and discusses the results, and Section 5 presents the concluding remarks and future research.

*Corresponding Author 


\section{OVERVIEW OF DRIP FERTIGATION METHODS}

Drip fertigation system is gradually gaining acceptance, and is becoming more attractive to many farmers since it supplies nutrients and water to the plant root zone more effectively than conventional planting [16]. To date, [17] have attempted to design an automatic irrigation system, but its implementation on actual farming sites has not been fully investigated. Another study to improve the drip irrigation technique was recently designed by [18]. Using this technique, farmers do not have to manually mix the fertilizer, which requires them to read the $\mathrm{EC}$ and $\mathrm{pH}$ of the mixture. Slow adoption of drip fertigation technology might be caused by low exposure, lack of expert techno-logical support, and the high cost of implementation, which includes hardware with computing, storage, and communication capabilities.

The automated drip fertigation system is more appealing to farmers worldwide, and has been gradually replacing conventional methods of farming. This is mainly due to the improvement in the quality of crops and agricultural products, as adequate nutrition is delivered directly to the plant root zone [19]. Such system saves significant amount of time when scheduled irrigation is performed remotely by turning pumps and valves on and off [20]. In a study done by [21], productivity for crops such as ginger shows increment in net income due to an increase in the yields of ginger. The crop productivity is almost doubled per hectare with an automatic drip fertigation system, compared to more conventional methods. Although the drip fertigation system requires a large amount of initial capital, the cost will be compensated by high crop productivity. In [22], the authors introduce a real-time irrigation system, named REUTIVAR, which calculates irrigation timing and fertilizer amount required in real-time using reclaimed water to watering olive tree. This technique will determine the timing of irrigation and fertigation events and can optimize fertilizer injection, the stabilization time and cleaning phase.

The development of useful new models based on the decision support system (DSS) has improved the automatic irrigation system [23-24]. An optimized DDS with a modified fertigation systems (DSS-FS) is designed primarily for drip and sprinkler irrigation, based on an environmental sustainability approach [25]. Meanwhile, [20] developed a DSS system to provide insight into the irrigation time required for a given crop and how irrigation schedules would change with soil types. All of these DSSs and models are very helpful in optimizing the use of water and fertilizer, and managing the centralized fertigation system in a water distribution network. However, the effects of occasional power outages on a scheduled drip fertigation system have not been investigated. Occasional power failures disrupt the time required for irrigation, unfortunately lead to an insufficient supply of water, and will affect crop growth.

In order to improve network performance to achieve more reliable smart farming system, an adaptive technique was introduced to maintain reliable network connection to transmit sensor data to base station by adaptively change the communication protocol between IEEE 802.11ac and LoRaWAN [26]. This technique is particularly useful to manage large farming sites at different location. On the other hand, Agri-Info, a cloud based autonomic resource management technique for agriculture service was introduced in order to maintain required level of QoS. This method makes use of Fuzzy logic for making decisions based on defined rules to diagnose status as well as schedule the resources automatically [27].

In Malaysia, farmers have started to use the automatic drip fertigation system. However, due to poor technical knowledge and the initial development cost of the system, the farmers prefer not to use the DSS, and decide to manage their planting based on their experience instead. This is also the reason farmers opt to hire workers to man-age scheduled irrigation through on-site monitoring during power failure, which is very tedious and time-consuming, and in doing so, results in high man-power utilization.

The lack of technological advancement in drip fertigation has left farmers with no option but to use the commercial irrigation controllers available at the market, which are preprogrammed to supply water at predefined intervals. Typical drip fertigation system uses a timer and a valve to turn on the water pump for irrigation. Fig. 1 shows a typical fertigation system that consists of a water tank, a timer, a water filter, a water pump, garden accessories, and a piping system to channel water to individual pots [28-29]. These pots are arranged horizontally on the ground or vertically with supporting poles. The water supply is pre-program and follows a preset schedule. The amount of water and nutrients required by each plant is different each week, and normally depends on the stage of growth. Table I shows the required amount of water and nutrients required during the first three weeks of growth [30]. This table indicates that $600 \mathrm{ml}$ is the total amount of water required per day for vegetables such as spinach and eggplants [31].

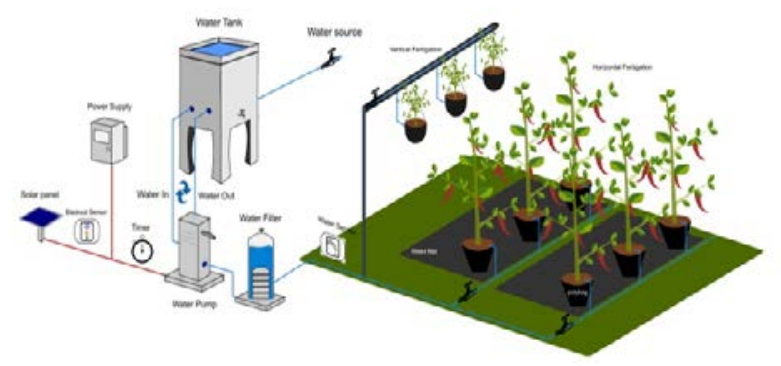

Fig. 1. The Fertigation System.

TABLE I. VOLUME OF WATER REQUIRED IN THREE WEEKS GROWTH

\begin{tabular}{|l|l|l|}
\hline No & Time (hrs) & Description \\
\hline 1 & 0730 & $150 \mathrm{ml}$ water and nutrient \\
\hline 2 & 0830 & $150 \mathrm{ml}$ water and nutrient \\
\hline 3 & 1100 & $150 \mathrm{ml}$ water \\
\hline 4 & 1700 & $150 \mathrm{ml}$ water \\
\hline
\end{tabular}


Medium- and small-scale drip fertigation farms still use the old and conventional method of observing the plantation site to check the growth of the plants. Field workers are required to monitor faults in the irrigation system and to perform regular checks on the plants' leaves and roots for possible plant disease infection. The only way to deter-mine poor plant growth is to examine the condition of the leaves and roots. Yellowish or wilting leaves are signs of poor growth. This farming workflow results in inefficient monitoring, especially when the plantation site holds thou-sands of pots. Fig. 2 shows the process in a fertigation system implemented for a local chili variety called Centil.

Centil (Capsicum Frustecens) is a type of red chili currently grown in Johor, Malaysia on a farming area with 1,000 pots [32]. Workers observe the irrigation process for 20 minutes in the morning and 20 minutes in the afternoon, and spend an additional 40 minutes every evening inspecting plants for general health and wilting leaves. They spend another 20 minutes in the evening inspecting for pests and diseases and administering pesticides. They perform maintenance and polybag cleaning once a week for 30 minutes. These processes are repeated until harvesting day. The detailed activities of the farming process are presented in Table II.

In areas where occasional power outages occur, the irrigation schedule, which is based on the needs of each plant, is often disturbed. Instead of turning to technological solutions, farmers prefer to hire more workers to look for faults in the irrigation system. With the current practice of having workers observe on-site, adding more workers to monitor faults results in inefficient irrigation management and high costs in labor, which in turn fails to offset the initial investment. Such a fertigation strategy defeats the purpose of an automatic irrigation and water management system, and could worsen depending on the solution taken by the farmers.

Previous work in the irrigation field focused on calculating irrigation requirements, where crop details fetched from the user were taken as input to estimate water requirements with the help of sensors. However, with scheduled irrigation, water and nutrient requirements cannot be fulfilled when the process is disturbed by an electrical power outage. Detailed information on the nutrients supplied is lost and irretrievable. The system shuts down, and the sensors do not capture information during the absence of electricity. This condition will go unnoticed without any notification to the farmers, and will last until power returns, which may take hours or even days. The problem becomes more serious during dry seasons and in remote farming areas, where farmers are not aware of such situations.

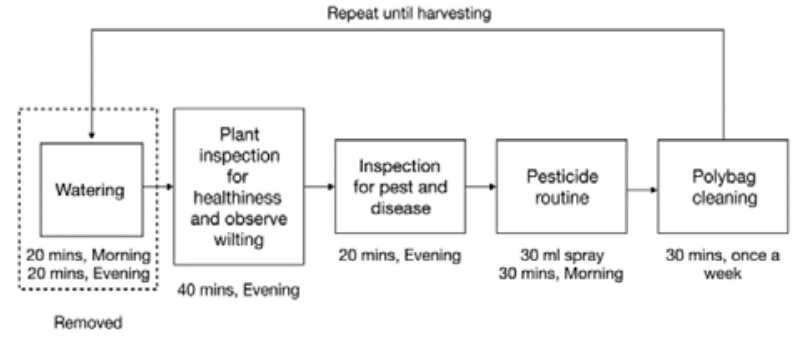

Fig. 2. Manual Process of Monitoring Plant Growth.
TABLE II. DETAILED ACTIVITIES FOR FERTIGATION FARMING

\begin{tabular}{|c|c|c|c|c|c|}
\hline Activity & $\begin{array}{l}\text { Detailed } \\
\text { activity }\end{array}$ & Note & Duration & Frequency & $\begin{array}{l}\text { No of } \\
\text { People }\end{array}$ \\
\hline \multirow{2}{*}{$\begin{array}{l}\text { Preparation } \\
\text { of plant bag }\end{array}$} & $\begin{array}{l}\text { 1. Turn on the } \\
\text { water pump to } \\
\text { see if there is } \\
\text { a pipe leak or } \\
\text { a clog. }\end{array}$ & \multirow{2}{*}{$\begin{array}{l}2-5 \\
\text { days } \\
\text { before } \\
\text { planting }\end{array}$} & 15 mins & once a day & 5 \\
\hline & $\begin{array}{l}\text { 2. Turn on the } \\
\text { water pump to } \\
\text { moisten the } \\
\text { soil before } \\
\text { planting the } \\
\text { seedlings. }\end{array}$ & & 15 mins & once a day & 5 \\
\hline \multirow{11}{*}{$\begin{array}{l}\text { Supervision } \\
\text { after } \\
\text { planting }\end{array}$} & $\begin{array}{l}\text { 1. Turn on the } \\
\text { water pump to } \\
\text { water the } \\
\text { seedlings. }\end{array}$ & \multirow{3}{*}{$\begin{array}{l}1-2 \\
\text { days } \\
\text { after } \\
\text { planting }\end{array}$} & 20 mins & morning & \multirow[t]{2}{*}{5} \\
\hline & \multirow{2}{*}{$\begin{array}{l}\text { 2. Ensure the } \\
\text { seedlings are } \\
\text { not infected } \\
\text { with pests and } \\
\text { diseases. }\end{array}$} & & 20 mins & afternoon & \\
\hline & & & 20 mins & once a day & 5 \\
\hline & \multirow{2}{*}{$\begin{array}{l}\text { 3. Turn on the } \\
\text { water pump to } \\
\text { fertilise the } \\
\text { seedlings for } \\
\text { the first time } \\
\text { and pour out } \\
\text { the stagnant } \\
\text { water. }\end{array}$} & \multirow{2}{*}{$\begin{array}{l}3 \text { days } \\
\text { after } \\
\text { planting }\end{array}$} & 20 mins & morning & \multirow{2}{*}{5} \\
\hline & & & 20 mins & afternoon & \\
\hline & \multirow{2}{*}{$\begin{array}{l}\text { 4. Turn on the } \\
\text { water pump } \\
\text { once every } \\
\text { morning to } \\
\text { fertilise the } \\
\text { plants. }\end{array}$} & \multirow{4}{*}{$\begin{array}{l}4-7 \\
\text { days } \\
\text { after } \\
\text { planting }\end{array}$} & 30 mins & morning & 5 \\
\hline & & & 40 mins & Afternoon & \\
\hline & $\begin{array}{l}\text { 5. Plant } \\
\text { inspection to } \\
\text { check whether } \\
\text { the plants are } \\
\text { healthy. }\end{array}$ & & 30 mins & once a day & 5 \\
\hline & $\begin{array}{l}\text { 6. Note if the } \\
\text { plant starts to } \\
\text { wither. If yes, } \\
\text { check the } \\
\text { piping system. }\end{array}$ & & 30 mins & once a day & 5 \\
\hline & \multirow{2}{*}{$\begin{array}{l}\text { 7. Fertilise the } \\
\text { plants twice a } \\
\text { day using the } \\
\text { fertigation } \\
\text { system. }\end{array}$} & \multirow{2}{*}{$\begin{array}{l}7 \text { days } \\
\text { after } \\
\text { planting }\end{array}$} & 20 mins & morning & 5 \\
\hline & & & 20 mins & afternoon & \\
\hline
\end{tabular}

All of these works provide interesting information on advanced technologies for irrigation systems, mostly focusing on optimizing water usage and crop productivity. However, any sensor data or video images of a given farm can-not be transmitted to a processing center or server in the absence of electricity. Under these circumstances, a system cannot perform real-time monitoring, which is crucial for agricultural applications. Real-time monitoring is essential because it provides timely information on the actual status of farming sites, such as the volume of water and fertilizer received, which is an important factor in improving crop production. Thus, having a system to access real-time data through a mobile application during power failure would allow farmers to respond and act to the situation in timely manner. 


\section{Methodology of The Proposed Solution}

In this section, we describe the complete system of the proposed automated monitoring system for watering and power outage alerts, with pesticide and polybag cleaning notifications. The proposed monitoring system comprises of three main components: (i) the overall system architecture; (ii) the sensor systems; and (iii) the mobile and web applications monitoring interfaces, as shown in Fig. 3.

In Fig. 3, a system administrator is in charge of the farming system. This figure also shows that the farmers will use the mobile application to monitor the system, receiving alerts and notifications, and interact with the system for pesticide scheduling and polybags maintenance. The watering and power outage sensors are designed to detect whether the plants have been watered, and to alert farmers through mobile notifications when a power failure occurs. The notifications and alerts are sent through Global System for Mobile Communications (GSM) to the internet service provider [33], then to a cloud server for data storage and processing.

\section{A. System Architecture}

Our proposed monitoring system, as shown in Fig. 4, consists of integration of sensors with the existing fertigation system. The water sensor will be installed in the main distribution pipe, and on the other hand, the power outage sensor will be installed on the power supply line. The proposed system was developed by taking into account the important layers of the IoT architecture [34]. We introduced another layer for troubleshooting and debugging the sensors. This includes fixing the devices' programming errors. In the second layer, we have our proposed watering and power outage detection sensors, which are connected to an Arduino-based processor for data processing. For data transmission to the cloud server, the devices connect wirelessly via a GSM module, which is on the third layer. The cloud server is on the fourth layer, where all data is sent using the "post" application programming interface (API) via a GSM module to the backend cloud processor. The cloud services will cover all "post" and "get" APIs from the GSM module and mobile applications. Lastly, we have a mobile application for monitoring and interaction, and a web server for managing the system, as shown in Fig. 5.

The interaction between the hardware, backend processor, and mobile applications is shown in Fig. 6. Arduino will send the "post" API to the backend processor on the cloud via a GSM module. When the backend processor receives the API, it will $\log$ it and update the record in the database. If a notification is required, backend processor will trigger the Firebase server, which will then push the notification to our mobile application so that farmers will receive the notification on their smartphones. For information updates, the mobile application will send the "post" and "get" APIs to request that the data be updated on the app. The cloud server acts as an intermediary between the sensors and the mobile application.

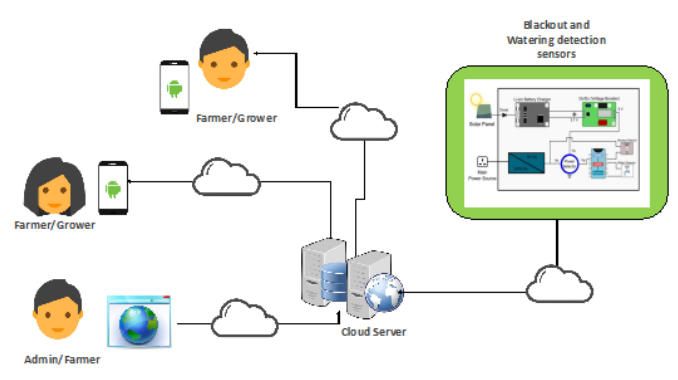

Fig. 3. Components of the Fertigation System.

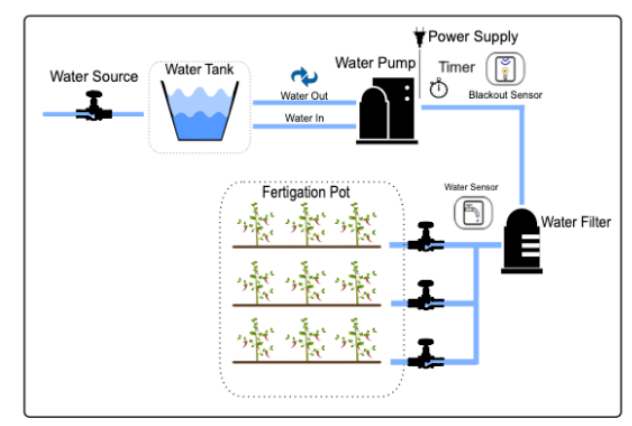

Fig. 4. The Proposed Fertigation System.

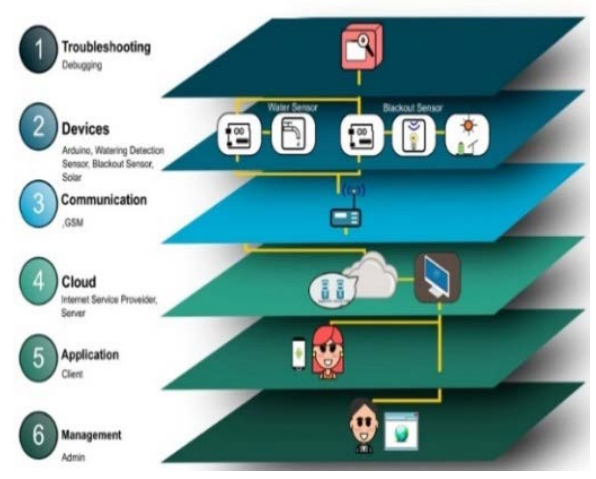

Fig. 5. Proposed System Architecture.

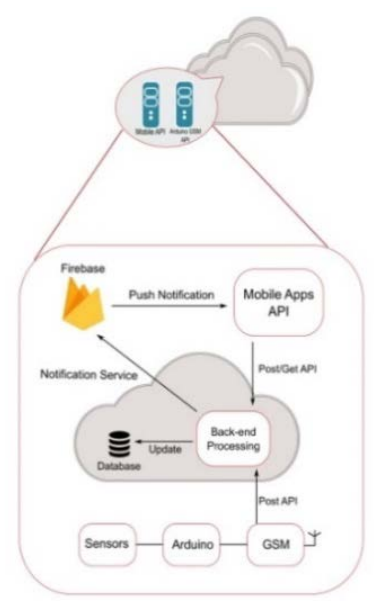

Fig. 6. The Interaction between Hardware, Mobile Apps and the Backend Server. 


\section{B. Sensor System}

The power outage sensor is powered by a 240 VAC main power source that in turn is converted to a direct current (DC), which provides nine VDC to the system by using an adaptor, as shown in Fig. 7. This is the main power source for the fertigation system. The auxiliary power comes from the solar panel, which charges a 3.7V 18650 Li-ion battery. The voltage from the battery is then boosted to $9 \mathrm{~V}$ and fed to a power selector circuit prior to Arduino. The power selector takes the power in such a way that the power always comes from the main power source, except during a power outage, when it takes the power from the charged battery.

This power switch is instantaneous, similar to an uninterrupted power supply (UPS), so that Arduino does not re-boot. In the event of a power outage, the system will automatically switch to the solar-powered battery. While the system is using the battery, the transition causes the system to send a "power down" API token through a GSM module to the backend processing cloud server. When the server receives the "power outage" API token, a power outage notification is sent to a Firebase server, which will then push it to the mobile application. The dashboard will display the power outage status, which will read "blackout has occurred" in red. This function notifies growers immediately when the system is no longer using the main power source. Thus, action can be taken to troubleshoot and to fix the problem. When the power outage sensor detects that the main source is functioning again, it will send the "power up" API to the server. Fig. 8 shows the flow of the power outage sensor. The flowchart shows that the "power down" API and the "power up" API are sent to the server only when there is a change in state.

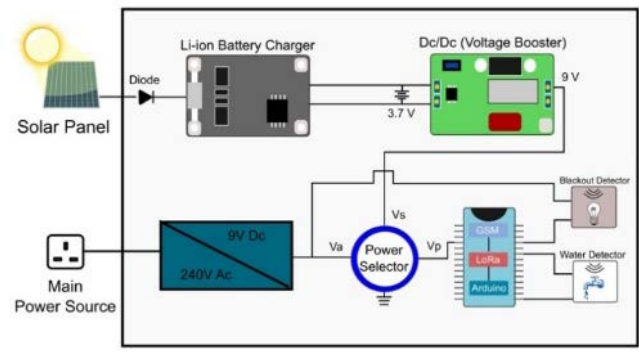

Fig. 7. The Watering and Power Outage Sensors for Fertigation System (Type A Module).

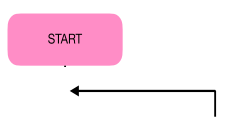

In the fertigation system, the watering schedule uses a timer to activate a water pump. The water pump releases water to the main pipe for a period of time determined by the volume of water needed for each plant. Therefore, it is crucial to know that the plant has been watered according to the schedule set by the farmers. In our proposed system, the water detection sensor is installed in the main pipe, where it will detect the presence of water. Water detection only happens if there is a change in the sensor as follows:

1) State 0 to 1 (No water is detected to Water is detected), API "watering start" is called.

2) State 1 to 0 (Water detected to No water) API “watering stop” is called.

Water detection is taken as an analogue input to Arduino. Upper and lower boundaries are required for water detection. The upper boundary is required to determine the presence of water, and the lower boundary lets the water subside in the pipe after the water pump has been turned off. The flowchart for watering detection is shown in Fig. 9.

Two states of mobile display are described as follows to let the farmers know the watering status.

1) Watering has started: Indicates that watering has been executed as scheduled and the water pump has been activated for a duration specified by user. This is activated when the sensor detects water, and the API "watering start" is called.

2) Watering has stopped: Indicates that watering has stopped, and the API "watering stop" is called when the sensor detects that the water has subsided below the lower boundaries.

We designed two modules, type A and type $\mathrm{B}$, for watering and power outage sensors. For type A, the watering and power outage sensors are combined in one module. This design is suitable for fertigation sites where watering sensors can be installed in close proximity to the power outage sensor.

The type B module shown in Fig. 10 is designed for large fertigation sites. The type $\mathrm{B}$ module allows the watering and power outage sensors to be installed in different locations, thus increasing the flexibility for extended range. We used Long Range (LoRa) connectivity [35-37] for greater connection between the watering and power outage detection sensors before data is sent to the cloud server via the GSM module. The GSM module requires a lot of power to transmit data to the server. The LoRa wireless transmission cannot run on the Arduino Uno processor due to its large memory requirement.

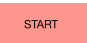

Fig. 8. Flow Chart for Power Outage Detection.
Fig. 9. Flow Chart for Watering Detection. 


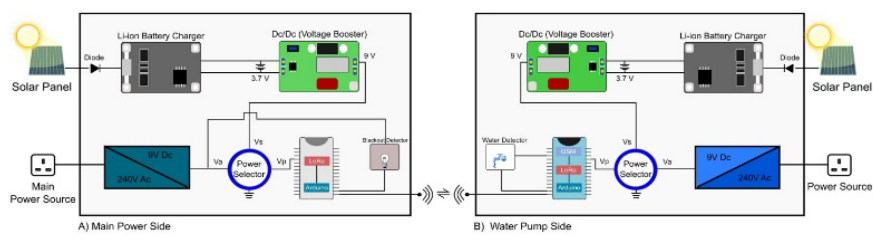

Fig. 10. The Watering and Power-outage Detection Sensors for Fertigation System (Type B Module).

\section{Software System and Mobile Monitoring Interfaces}

To ensure our watering and power outage detection sensors are functional 24 hours a day, Arduino will send the "I am alive" API to the server every hour. The backend processor will receive this "post" API and update the database. This information will be sent to the mobile apps when they send the "get" API, and the "sensor is online" status will appear on the mobile app dashboard. The "I am alive" flowchart is shown in Fig. 11. However, if the server does not receive this API, it will state that the system is not working and post this status on the mobile app's dashboard.

Table III shows all the "get" APIs, from the hardware to the backend processor. The backend processor will act according to the API, whether it receives data to record changes in the database or to send a notification to a Firebase server.

The proposed system consists of a web application for a system administrator or head farmer to efficiently manage the planting cycle. Fig. 12 shows the administrator page, where the administrator is responsible for adding the following information to the system.

1) Planting schedule: The planting schedule will have the total time of growth, from first transplanting to harvesting. The schedule contains information on when to spray pesticides and when the polybag should be maintained by which group of farmers.

2) Authorizing the users (farmers) in the system and assigning them to specific groups.

3) Watering schedule: How many times the farmers need to water the plants.

4) Adding the pesticide routine and assigning different groups to perform the activity.

5) Assigning polybags cleaning to different groups.
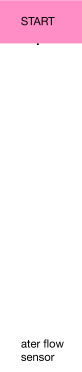

Fig. 11. "I am Alive” Flowchart to System Checking.
TABLE III. APIS USED FROM HARDWARE TO BACKEND SERVER

\begin{tabular}{|l|l|}
\hline API & Descriptions \\
\hline Watering Start & $\begin{array}{l}\text { Water is detected. Change of state from water=0 to } \\
\text { water=1 }\end{array}$ \\
\hline Watering Stop & $\begin{array}{l}\text { Water is not detected. Change of state from water=1 to } \\
\text { water=0 }\end{array}$ \\
\hline Power up & $\begin{array}{l}\text { Main supply is detected. Change of state from power=solar } \\
\text { to power=main }\end{array}$ \\
\hline Power down & $\begin{array}{l}\text { Main supply is not detected. Change of state from } \\
\text { power=main to power=solar }\end{array}$ \\
\hline I am alive & $\begin{array}{l}\text { Indicates the hardware is functioning properly. If alive, } \\
\text { status=1. If not, status=0 }\end{array}$ \\
\hline
\end{tabular}
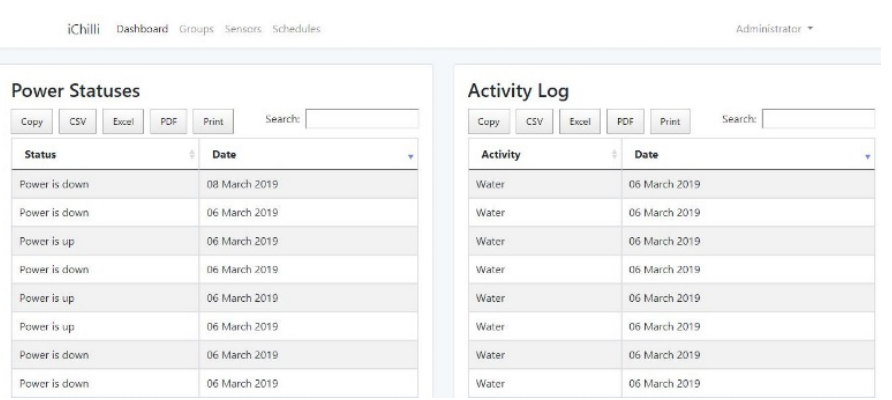

Fig. 12. The Webpage for System Administrator.

A smartphone application, called iChilli, was developed to manage planting activities more efficiently. Table IV shows the functionality of the iChilli user interface (UI). The iChilli apps displays the front page, registration page, blackout status, polybag cleaning, history, pesticide control status, and schedules. The Android-based application was developed for the following purposes:

1) To alert farmers when a power failure occurs so they can respond to it.

2) To notify farmers of the watering status so they can follow the schedule.

3) To show the history of watering so farmers can estimate the volume of water their plants received.

4) To manage pesticide activity and record the type and volume of pesticide used.

5) To assign farmers to maintain the fertigation site with activities such as cleaning and weeding.

6) To manage the planting cycle by showing the schedule for planting activities.

TABLE IV. FEATURES OF THE SMART PHONE

\begin{tabular}{|l|l|}
\hline \multirow{4}{*}{ Dashboard } & Blackout status \\
\cline { 2 - 2 } & Watering status \\
\cline { 2 - 2 } & Pesticide \\
\cline { 2 - 2 } & Polybag cleaning \\
\hline Blackout history & By selected date \\
\hline Watering history & By selected date \\
\hline \multirow{3}{*}{ Pesticide control } & Status: Done/Not Done \\
\cline { 2 - 2 } & Type: Organic/Non organic \\
\cline { 2 - 2 } & Quantity in Litre \\
\hline \multirow{2}{*}{ Polybag cleaning } & Status: Done/Not Done \\
\cline { 2 - 2 } & Which group performed the task \\
\hline Full schedule & Day-date-time activities \\
\hline
\end{tabular}




\section{Implementation and Evaluation}

To validate our system, type A watering and power outage sensors were installed at the fertigation site. A water tank with a capacity of 70 litres and a water piping system capable of watering 1000 pots of plants are shown in Fig. 13. The farming activities under the fertigation system for the red chili Centil were used for benchmarking.

\section{E. Wireless Connection to Cloud Server via Internet Service Provider}

A GSM module is used to send data to a server in the cloud. The module is connected to the internet service provider, enabling APIs to be sent to the server. The GSM module has an LED indicator that blinks rapidly every second the GSM is not connected to the network. When the module is sending a request signal to connect to the network, the LED blinks every three seconds, and, when the blinking reaches an even slower speed, it indicates that the net-work connection has been established. Since connecting to the network requires a high current consumption, an adaptor with power ration of $9 \mathrm{~V} 2 \mathrm{~A}$ is used to power up the GSM module as shown in Fig. 14.

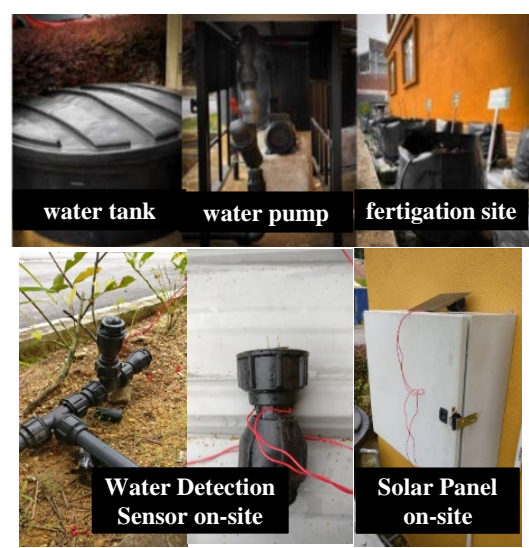

Fig. 13. The Fertigation Site where the System is Installed.

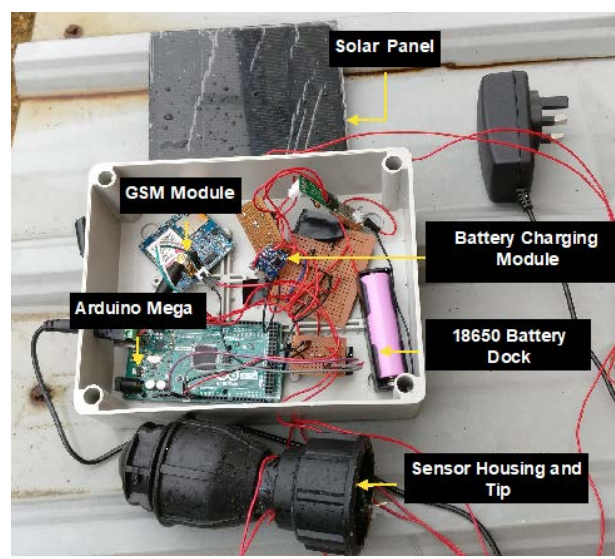

Fig. 14. The Electronic Hardware of the System.

\section{RESUlt AND Discussion}

We discuss two elements for improvement. The first element involves the farming work-flow, and the second involves design-related module performance.

\section{A. Improving Farming Work-Flow by the System}

The proposed system automates the first block in Fig. 2 (namely "watering”), which has been identified as inefficient in growth monitoring. Workers are required to be on-site to observe the watering for 20 minutes in the morning and 20 minutes in the afternoon. The proposed system improved the farming work-flow by reducing manpower while maintaining the same yield production. Manpower was calculated based on three variables: project duration, number of hours per worker, and number of workers. The project duration for the chili Centil, from transplant to harvest, was six months. A worker worked for five days a week to perform daily tasks, as shown in Fig. 2 that include:

1) Observe watering: 40 minutes.

2) Plant inspection to check for health: 40 minutes.

3) Inspection for disease: 20 minutes.

Thus, the three tasks required 100 minutes (1.67 hours) for each worker per day. The calculation considered 20 working days per month for six months (120 days). The manpower calculation is shown in Table $\mathrm{V}$.

A typical fertigation-based system requires 200.4 hours, whereas the proposed system requires 120 hours. Thus, with this system, we reduce man-power by $40 \%$. The man-hour reduction would be more significant for a big farming site that requires extensive monitoring. Five workers are required for 1,000 plants, which means a larger farm's manpower can be further reduced. In the cost relationship shown in Fig. 15, the reduction in man-hours not only improved the operational cost, but increased the yield production as well.

TABLE V. MAN-POWER CALCULATION

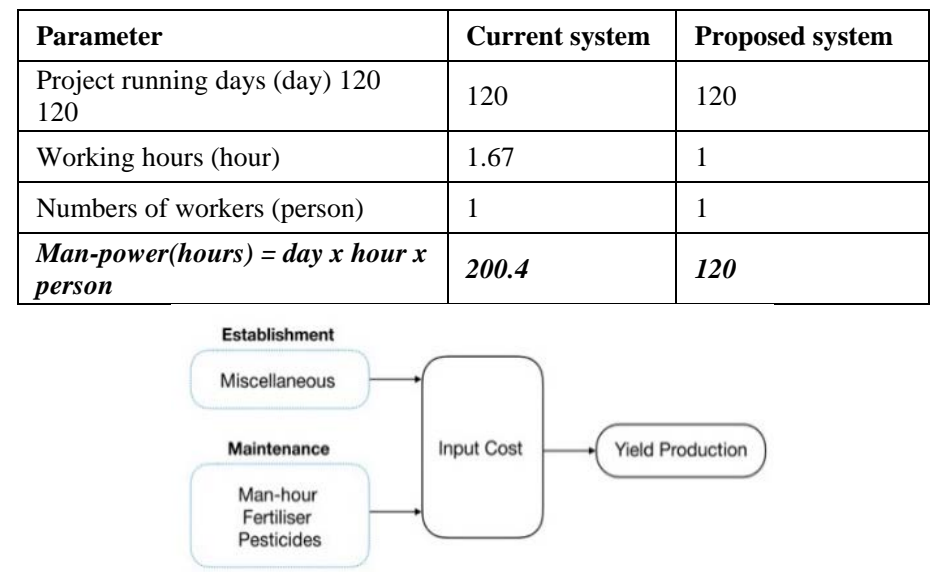

Fig. 15. Relationship between Man-hour to Yield Production. 


\section{B. Water Detection Sensor}

The experiments were performed using two types of watering detection sensors. The first type was custom designed with two protruding gold pins. The pins are not connected electrically, and act as a switch. Without water presence, the sensor has an extremely low voltage (around 0.0-0.4 volts). However, when water is flowing, depending on how submerged the pins are or how strong the flow is, when more of the pins' surface area is covered with water, the voltage will increase. At the highest water flow, it is possible to achieve over 2.8 volts across the pins. In a perfect water flow system, the value will drop or rise instantly between the "water detection" and "water not detected" stages. However, due to the nature of the pipes used, some excess water may still be present in the pipes when the water stops flowing. Thus, the voltage drop is not instantaneous.

For example, from high water flow we will get 2.8 volts, and the voltage drops to 2.5 volts when the pump is stopped. As time progresses, the voltage will decrease as the water flows towards the end of the piping system and water levels drop slowly. However, this value is constantly fluctuating due to the formless nature of water, which causes some motion within the pipe. As such, it can be deduced that an optimal "water detection" voltage value would be any voltage higher than 2.7 volts (upper boundary) and "water not detected" can be any value below that (lower boundary). When the water pump is activated, there will be an instant rise in voltage, exceeding the upper boundaries, and a sudden drop in voltage to below the lower boundaries over a short period of time. Therefore, a few seconds are given for the sensor to stabilize before the API "watering start" is sent to the server.

Other experiments were conducted with a typical inline water flow sensor made for an Arduino-based environment with three pole connections for $5 \mathrm{~V}$ voltage input, one digital data pin, and a ground pin. However, the digital pin does not connect to the standard digital input pins on Arduino, but must be connected to Arduino where Pulse Width Modulation (PWM) is allowed. This connection enables Arduino to make the necessary calculations to transcribe data from the sensor into a readable format for the user. The sensor functions through the rotational motion created by an electric rotor. The rotational speed of this rotor depends on the rate of water travelling through the sensor. The sensor, which is based on the Hall effects phenomenon, will then send a corresponding pulse signal to Arduino. The rate at which the pulse signal is received will directly correlate to the rate of water flow: that is, slower pulses mean a lower flow rate, while faster pulses mean a higher rate.

An “API Start” API token is sent when the upper boundary is reached. We calculated the upper boundary by measuring the reading of the irrigation system. The lower boundary for sending the "watering stop" API token was set to zero. This is because when the water flow stops, even though there may still be water in the pipes, the value of the water flow will be set to 0 as long as the water is not moving. The measured value of the water flow was calculated in liter per minute $(\mathrm{l} / \mathrm{m})$. Some precautionary steps were taken when using the water flow sensor. Firstly, the water flow sensor had a small diameter to allow a pipe to fit on it. Appropriate adaptors were used when the pipe was larger than the hole of the water flow sensor. Secondly, most commercial Arduino-based water flow sensors have a maximum flow rate of $30(\mathrm{l} / \mathrm{m})$. In addition, it is unclear if higher water flow directly influences the accuracy and efficiency of the water flow sensor. It is currently unclear if this damages or adversely affects the sensor in any way.

\section{Battery-Powered Solar Cell Charging and Discharging Rate}

Since the system is operated by a back-up battery in the case of power failure, we analyzed the total operating time of the back-up supply by studying the battery's charge and discharge time. To control the charging process as well as to protect the battery from overcharging, the level at which the battery will supply sufficient power was noted.

An experiment was conducted to study the rate of power loss for the 18650 battery over time without direct power from the mains. The experiment was conducted with the system running, and voltage measurements were taken across the battery. The experiments were conducted a few times, and the average readings were calculated. The result of the discharge time is illustrated in Fig. 16.

Experiment 1 in Fig. 16 shows the voltage loss over time for a battery initially charged up to $4 \mathrm{~V}$. There is a slow semilinear loss of voltage over time until around $3.3 \mathrm{~V}$, where the voltage will reduce exponentially until a value of $2.2 \mathrm{~V}$ is reached. Experiment 2 was conducted to determine whether this pattern could be replicated. Experiment 2 shows the voltage loss over time for a battery that has been fully charged to $4.17 \mathrm{~V}$. Similar to the first experiment, the voltage indicates a slow, semi-linear decrease until around $3.3 \mathrm{~V}$, where the rate of voltage discharge increases tremendously in an exponential fashion. It can also be seen that the final voltage of $2.2 \mathrm{~V}$ will remain for a period of time and will not decrease further. During these experiments, the system was able to run as long as the voltage was above $2.2 \mathrm{~V}$; however, after this point, although the voltage did not decrease further, Arduino and the GSM module would be off. This indicated that the system did not have the required power to run. Experiment 1 showed that the sys-tem can run up to 6.7 hours, whereas experiment 2 showed that the system can last for 8.3 hours de-pending on the initial charged voltage of the battery.

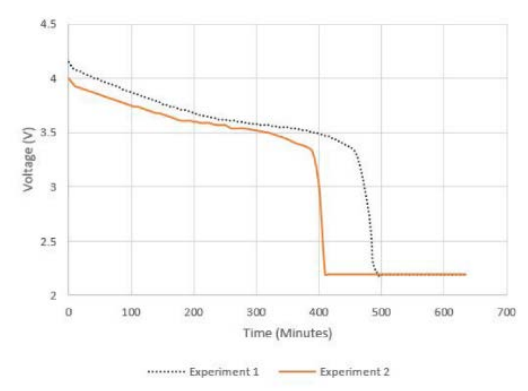

Fig. 16. Discharge Voltage over Time for Battery Powered Solar Cell.

\section{Study of Switching during Power Outage}

In the event of power failure, supply is cut off from the main. The designed circuit instantaneously switches to the battery charged by the solar cell. The switching processes from 
main supply to battery and vice versa were observed in terms of response time. In this case, the transient response of the transition time for both cases was observed. There is a small period in which the module switches to a new power source when another has stopped. Fig. 17(a) shows the voltage against the transition time between main supply and battery-powered operation. On the contrary, Fig. 17(b) shows the transient result of the voltage of the switching state between battery-operated to the adaptor-operated supplies.

Fig. 17 shows that it took 400 microseconds for both situations to switch from one state to another, as de-noted by the bandwidth of both pulses. Essentially, when the states are switched from one power source to another, this creates a transient that can be measured as denoted by the peaks in the graph. Thus, the time it takes for the switching to occur is measured by the time it takes for the transient peak to rise and fall. A short switch time is ideal, as it ensures that the system will have constant power and can efficiently switch between power sources with minimal transition. Arduino will go to reset state if the transition takes too long, and the whole system will be reset.

\section{E. Comparison Study}

Table VI highlights the comparison between the proposed system and the previously developed intelligent systems in term of key features that record real-time irrigation of plants, the duration of scheduled irrigation for each cycle, the history of nutrients supplied to the plants, and, more importantly, an alert sent to farmers so that quick action can be taken during a power outage to prevent severe damage to the plants. Our monitoring system is an attempt to present a solution that records the length of the irrigation process, notifies farmers in the event of power failure, and tracks the irrigation history through an easy-to-use mobile application that guides farmers and farm workers. The solution is a user-friendly platform that does not require any knowledge of programming.

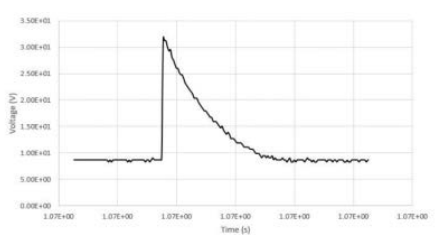

(a)

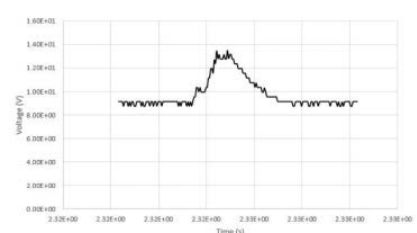

(b)
Fig. 17. Switching Time Tansitions: (a) Transition between Adaptor-operated to Battery-operated Power Supplies, (b) Transition Time between Batteryoperated to Adaptor-operated Power Supplies.

TABLE VI. COMPARISON TABLE OF PREVIOUS WORK

\begin{tabular}{|c|c|c|c|c|c|c|}
\hline \multirow[b]{2}{*}{ Work } & \multicolumn{6}{|l|}{ Features } \\
\hline & Feature 1 & Feature 2 & $\begin{array}{l}\text { Web or } \\
\text { Mobile Apps }\end{array}$ & $\begin{array}{l}\text { Agriculture } \\
\text { Domain }\end{array}$ & Connectivity & $\begin{array}{l}\text { Cloud } \\
\text { Resources }\end{array}$ \\
\hline [1] & $\begin{array}{l}\text { Monitoring and automatic irrigation } \\
\text { system on crop water needs and real } \\
\text { time and history of farm data }\end{array}$ & $\begin{array}{l}\text { Neural based irrigation decision for } \\
\text { ecient irrigation }\end{array}$ & Yes & $\begin{array}{l}\text { Greenhouse } \\
\text { irrigation }\end{array}$ & WiFI & Yes \\
\hline [4] & $\begin{array}{l}\text { a flexible platform able to cope with } \\
\text { soilless culture needs in full } \\
\text { recirculation greenhouses using } \\
\text { moderately saline water }\end{array}$ & $\begin{array}{l}\text { three-tier open source software } \\
\text { platform that distributes computing } \\
\text { at Cyber Physical Systerm, edge } \\
\text { and cloud planes }\end{array}$ & No & $\begin{array}{l}\text { Precision } \\
\text { agriculture, } \\
\text { greenhouse }\end{array}$ & $\begin{array}{l}\text { Microwave } \\
\text { radio link, } \\
\text { fiber optic, } \\
\text { DSL }\end{array}$ & Yes \\
\hline [5] & $\begin{array}{l}\text { a scalable network architecture for } \\
\text { monitoring and controlling agriculture } \\
\text { and farms in rural areas }\end{array}$ & $\begin{array}{l}\text { a cross-layer-based channel access } \\
\text { and routing solution for sensing and } \\
\text { actuating }\end{array}$ & No & $\begin{array}{l}\text { Smart } \\
\text { farming }\end{array}$ & $\begin{array}{l}\text { LoWPAN, } \\
\text { IEEE } \\
802.15 .4 \text {, } \\
\text { WiFi }\end{array}$ & Yes \\
\hline [22] & $\begin{array}{l}\text { REUTIVAR-calculates in real-time } \\
\text { irrigation time and fertilizer amount } \\
\text { required to olive tree using reclaimed } \\
\text { water }\end{array}$ & $\begin{array}{l}\text { Adaptive fertigation scheduling } \\
\text { according to the actual weather } \\
\text { conditions and adjusted the water } \\
\text { allocation along the irrigation } \\
\text { season }\end{array}$ & Yes & Irrigation & $\begin{array}{l}\text { Mobile Server, } \\
\text { SqLite }\end{array}$ & $\begin{array}{l}\text { No, local } \\
\text { server }\end{array}$ \\
\hline [23] & $\begin{array}{l}\text { a user-friendly decision support system } \\
\text { tool for the optimization of the design } \\
\text { and management of on-farm fertigation }\end{array}$ & $\begin{array}{l}\text { determine the timing of irrigation } \\
\text { and fertigation events and optimize } \\
\text { fertilizer injection, the stabilization } \\
\text { time and cleaning phase }\end{array}$ & No & $\begin{array}{l}\text { Drip } \\
\text { fertigation }\end{array}$ & No & No \\
\hline [26] & $\begin{array}{l}\text { Improve network performance to } \\
\text { achieve more reliable smart farming } \\
\text { system }\end{array}$ & $\begin{array}{l}\text { Adaptive technique to maintain } \\
\text { reliable network connection to } \\
\text { transmit sensor data to base station } \\
\text { by adaptively change the } \\
\text { communication protocol between } \\
\text { IEEE 802.11ac and LoRaWAN }\end{array}$ & No & $\begin{array}{l}\text { Smart } \\
\text { farming }\end{array}$ & $\begin{array}{l}\text { LoRaWan and } \\
\text { IEEE802.11ac }\end{array}$ & No \\
\hline [27] & $\begin{array}{l}\text { Agri-Info, a cloud based autonomic } \\
\text { resource management technique for } \\
\text { agriculture service and maintain } \\
\text { required level of QoS }\end{array}$ & $\begin{array}{l}\text { Fuzzy logic for making decisions } \\
\text { based on defined rules to diagnose } \\
\text { status as well as schedule the } \\
\text { resources automatically }\end{array}$ & Yes & $\begin{array}{l}\text { Agriculture- } \\
\text { as-a-Service }\end{array}$ & $\begin{array}{l}\text { Agriculture- } \\
\text { as-a-Service }\end{array}$ & Yes \\
\hline $\begin{array}{l}\text { Our } \\
\text { proposed } \\
\text { system }\end{array}$ & $\begin{array}{l}\text { Real-time irrigation tracking and record } \\
\text { with alert to notify farmer during power } \\
\text { outage }\end{array}$ & $\begin{array}{l}\text { Tracking and recording for pesticide } \\
\text { and maintenance }\end{array}$ & Yes & $\begin{array}{l}\text { Drip } \\
\text { fertigation }\end{array}$ & $\begin{array}{l}\text { GSM } \\
\text { module }\end{array}$ & Yes \\
\hline
\end{tabular}




\section{F. Limitation and Future Work}

The developed system was developed for chili fertigation farming of 1000 pots of plant. So far, it also only been tested in a location that is prone to electrical blackout. Although, the results show significant improvement over the conventional method applied on the same scope, the results and performance will be more accurate if the system is tested over various kinds of plants with larger pots ( 2000 pots and more) and the data are observed over longer period of time i.e. three to six months. Furthermore, the proposed system should also be tested in various locations that are prone to blackouts to further evaluate is effectiveness and efficiency.

\section{CONCLUSION}

In this paper, we have demonstrated a systematic and automated method for monitoring large-scale chili fertigation area in order to improve the farm management efficiency and consequently to improve plant growth in a power-outage-prone area. The system, which consists of sensors for detecting irrigation activities and power outages, a mobile application to manage scheduling for pesticide delivery and polybag cleaning, and a web application to al-low farmers to manage planting schedules has shown improvement in efficiency in farming management, with a $40 \%$ reduction in manpower in this power outage-prone area, compared to a typical fertigation-based farming sys-tem in such area. The proposed system also exhibited greater control over plant growth and automatically records pesticide schedules and polybag cleaning, all of which could improve crop yields. We believe the findings and the method of using IoT platform as a systematic monitoring mechanism, presented in this paper, will pave the way and encourage further use in broader plant types, which could prove useful in a large farming area in rural sites.

\section{ACKNOWLEDGMENT}

The research was supported by research grants: DCP-2018001/2, FRGS/1/2020/STG07/UKM/02/3, and GUP-2017-068.

\section{REFERENCES}

[1] N. K. Nawandar, V. R. Satpute, "IoT Based Low Cost and Intelligent Module for Smart Irrigation System”. Computers and Electronics in Agriculture, Vol. 162, 2019, pp. 979-990.

[2] W. Wang, Y. Cui, Y. Luo, Z. Li, J. Tan, "Web-Based Decision Support System for Canal Irrigation Man-agement". Computers and Electronics in Agriculture, Vol. 161, 2019, pp.312-321.

[3] A. Goap, D. Sharma, A. Shukla, C. R. Krishna, "An IoT Based Smart Irrigation Management System using Machine Learning and Open source Technologies”. Computers and Electronics in Agriculture, Vol. 155, 2018, pp.41-49.

[4] M. A. Zamora-Izquierdo, J. Santa, J. A. Martinez, V. Martinez, A. F. Skarmeta, "Smart Farming IoT Plat-form Based on Edge and Cloud Computing”. Biosystems Engineering, Vol. 177, 2019, pp.4-17.

[5] N. Ahmed, D. De, I. Hussain, "Internet of Things (IoT) for Smart Precision Agriculture and Farming in Ru-ral Areas”. IEEE Internet of Things Journal, Vol. 5, No. 6, 2018, pp.4890-4899.

[6] D. Pivoto, P. D. Waquil, E. Talamini, C. P. S. Finocchio, V. F. Dalla Corte, G. de Vargas Mores, "Scientific Development of Smart Farming Technologies and Their Application in Brazil”. Information Processing in Agriculture, Vol. 5, No. 1, 2018, pp.21-32.

[7] E. A. Abioye, M. S. Z. Abidin, M. S. A. Mahmud, S. Buyamin, M. H. I. Ishak, M. K. I. Abd Rahman, A. O. Otuoze, P. Onotu, M. S. A. Ramli, "A Review on Monitoring and Advanced Control Strategies for
Precision Irrigation”. Computers and Electronics in Agriculture, Vol. 173, 2020, pp.105441.

[8] R. G. Perea, E. C. Poyato, P. Montesinos, J. R. Diaz, "Prediction of Irrigation Event Occurrence at Farm Level using Optimal Decision Trees”. Computers and Electronics in Agriculture, Vol. 157, 2019, pp.173-180.

[9] Y. Osroosh, R. T. Peters, C. S. Campbell, Q. Zhang, "Comparison of Irrigation Automation Algorithms for Drip-Irrigated Apple Trees". Computers and Electronics in Agriculture, Vol. 128, 2016, pp.87-99.

[10] S. A. Nikolidakis, D. Kandris, D. D. Vergados, C. Douligeris, "Energy Efficient Automated Control of Irriga-tion in Agriculture by Using Wireless Sensor Networks". Computers and Electronics in Agriculture, Vol. 113, 2015, pp.154-163.

[11] N. Zapata Ruiz, I. Chalghaf, E. Nerilli, B. Latorre Garces, C. Lopez Marin, A Martinez-Cob, J. Girona, E. Playan Jubillar, "Software for OnFarm Irrigation Scheduling of Stone Fruit Orchards Under Water Limita-tions”. Computers and Electronics in Agriculture, Vol. 88, 2012, pp.52-62.

[12] K. X. Soulis, S. Elmaloglou, "Optimum Soil Water Content Sensors Placement for Surface Drip Irrigation Scheduling in Layered Soils". Computers and Electronics in Agriculture, Vol. 152, 2018, pp.1-8.

[13] E. A. Dar, A. Brar, K. Singh, "Water Use and Productivity of Drip Irrigated Wheat Under Variable Climatic and Soil Moisture Regimes in Northwest India”. Agriculture, Ecosystems \& Environment, Vol. 248, 2017, pp.9-19.

[14] D. Yang, S. Li, S. Kang, T. Du, P. Guo, X. Mao, L. Tong, X. Hao, R. Ding, J. Niu, "Effect of Drip Irrigation on Wheat Evapotranspiration, Soil Evaporation and Transpiration in Northwest China". Agricultural Wa-ter Management, Vol. 232, 2020, pp.106001.

[15] R. Liu, Y. Yang, Y. S. Wang, X. C. Wang, Z. Rengel,W. J. Zhang, L. Z. Shu, "Alternate Partial Root-Zone Drip Irrigation with Nitrogen Fertigation Promoted Tomato Growth, Water and Fertilizer-Nitrogen Use Effi-ciency”. Agricultural Water Management, Vol. 233, 2020. pp.106049.

[16] E. Suarez-Rey, M. Gallardo, M. Romero-Gamez, C. Gimenez, F. Rueda, "Sensitivity and Uncertainty Analysis in Agro-Hydrological Modelling of Drip Fertigated Lettuce Crops under Mediterranean Condi-tions”. Computers and Electronics in Agriculture, Vol. 162, 2019, pp.630-650.

[17] A. Rasyid, N. Shahidan, M. Omar, N. Hazwani, J. Choo, "Design and Development of Irrigation System for Planting Part 1", in 2nd Integrated Design Project Conference (IDPC), pp. 1-22. 2015.

[18] B. Aisham, A. Rahim, "Design of Reservoir Tanks Modelling to Mix Several Types of Fertilizer for Fertiga-tion Planting System: Part B", in Journal of Physics: Conference Series, IOP Publishing. Vol. 1150, No. 1, p. 012022. 2019.

[19] R. Prabha, E. Sinitambirivoutin, F. Passelaigue, M. V. Ramesh, "Design and Development of an IoT Based Smart Irrigation and Fertilization System for Chilli Farming”, in 2018 IEEE International Conference on Wireless Communications, Signal Processing and Networking (WiSPNET), pp. 1-7. 2018.

[20] E. Wang, S. Attard, A. Linton, M. McGlinchey, W. Xiang, B. Philippa, Y. Everingham, "Development of a Closed-Loop Irrigation System for Sugarcane Farms using the Internet of Things". Computers and Electronics in Agriculture, Vol. 172, 2020, pp.105376.

[21] M. Y. Suhaimi, A. M. Mohamad, M. N. F. Hani, "Potential and Viability Analysis for Ginger Cultivation using Fertigation Technology in Malaysia”. International Journal of Innovation and Applied Studies, Vol. 9, No. 1, 2014, pp.421.

[22] C. A. Zaragoza, R. G. Perea, I. F. Garcia, E. C. Poyato, J. A. R. Diaz, "Open Source Application for Opti-mum Irrigation and Fertilization using Reclaimed Water in Olive Orchards". Computers and Electronics in Agriculture, Vol. 173, 2020, pp.105407.

[23] R. G. Perea, M. Moreno, J. Ortega, A. del Castillo, R. Ballesteros, "Dynamic Simulation Tool of Fertigation in Drip Irrigation Subunits". Computers and Electronics in Agriculture, Vol. 173, 2020, pp.105434.

[24] N. J. Car, "Using Decision Models to Enable Better Irrigation Decision Support Systems”. Computers and Electronics in Agriculture, Vol. 152, 2018, pp.290-301. 
[25] J. M. Barradas, S. Matula, F. Dolezal, "A Decision Support SystemFertigation Simulator (DSS-FS) for De-sign and Optimization of Sprinkler and Drip Irrigation Systems". Computers and Electronics in Agricul-ture, Vol. 86, 2012, pp.111-119.

[26] R. M. Rusyadi, P. T. Daely, D. S. Kim, J. M. Lee, "IoT-Based Adaptive Network Mechanism for Reliable Smart Farm System”. Computers and Electronics in Agriculture, Vol. 170, 2019, pp.105287.

[27] S. Singh, I. Chana, R. Buyya, "Agri-Info: Cloud Based Autonomic System for Delivering Agriculture as a Service”. Internet of Things, Vol. 9, 2020, pp.100131.

[28] R. Thompson, I. Delcour, E. Berckmoes, E. Stavridou, The Fertigation Bible: Technologies to Optimise Fertigation in Intensive Horticulture, 2018.

[29] J. M. Salih, A. Adom, A. M. Shaakaf, "Solar Powered Automated Fertigation Control System for Cucumis Melo L. Cultivation in Green House”. APCBEE Procedia, Vol. 4, 2012, pp.79-87.

[30] Z. Sayuti, H. Ahmad, A. K. Sandrang, Inovasi Pertanian Bandar. Penerbit MARDI. 2018.

[31] N. A. S. Hanifah, M. A. Rashid, A. Jupri bin Ahmat, "Fruit Yield, Fruit Quality and Seed Yield of Four Chilli Varieties Grown in Open-Field as Affected by Conventional System in Peat Soil Area and Fertigation System”, in 15th International Peat Congress, Sarawak, Malaysia, August 2016.
[32] A. Adam, K. P. Ee, N. Sahari, A. Tida, C. Y. Shang, K. M. Tawie, S. Kamarudin, H. Mohamad, et al., "Dr. Lada: Diagnosing Black Pepper Pest and Diseases with Decision Tree". International Journal on Advanced Science, Engineering and Information Technology, Vol. 8, 2018, pp.1584-1590.

[33] M. Zaman, R. Azim, N. Misran, M. Asillam, T. Islam, "Development of a Semielliptical Partial Ground Plane Antenna for RFID and GSM-900”. International Journal of Antennas and Propagation, Vol. 2014, 2014.

[34] S. Axryd, T. Chari, "A Digital Solution Towards Data-Driven Agriculture in Malaysia”. https://www.digitalnewsasia.com/insights/digi tal-solution-towards-data-driven-agriculture-malaysia, Febu-ary 2019.

[35] N. A. A. Husein, A. H. A. Rahman, D. P. Dahnil, "Evaluation of LoraBased Air Pollution Monitoring Sys-tem". International Journal of Advanced Computer Science and Applications, Vol. 10, No. 7, 2019, pp.391-396.

[36] M. Shahidul Islam, M. T. Islam, A. F. Almutairi, G. K. Beng, N. Misran, N. Amin, "Monitoring of the Hu-man Body Signal Through the Internet of Things (IoT) Based Lora Wireless Network System". Applied Sciences, Vol. 9, No. 9, 2019, pp.1884.

[37] M. Hossinuzzaman, D. P. Dahnil, "Enhancement of Packet Delivery Ratio During Rain Attenuation for Long Range Technology". International Journal of Advanced Computer Science and Applications, Vol. 10, No. 10, 2019, pp.219-225. 